University of Nebraska - Lincoln

DigitalCommons@University of Nebraska - Lincoln

Roman L. Hruska U.S. Meat Animal Research

U.S. Department of Agriculture: Agricultural Center

Research Service, Lincoln, Nebraska

2014

Effects of decreased dietary roughage concentration on energy metabolism and nutrient balance in finishing beef cattle

\author{
K. E. Hales \\ USDA-ARS, kristin.hales@ars.usda.gov \\ T. M. Brown-Brandl \\ USDA-ARS, Tami.BrownBrandl@ARS.USDA.GOV
}

H. C. Freetly

USDA-ARS, harvey.freetly@ars.usda.gov

Follow this and additional works at: https://digitalcommons.unl.edu/hruskareports

Hales, K. E.; Brown-Brandl, T. M.; and Freetly, H. C., "Effects of decreased dietary roughage concentration on energy metabolism and nutrient balance in finishing beef cattle" (2014). Roman L. Hruska U.S. Meat Animal Research Center. 264.

https://digitalcommons.unl.edu/hruskareports/264

This Article is brought to you for free and open access by the U.S. Department of Agriculture: Agricultural Research Service, Lincoln, Nebraska at DigitalCommons@University of Nebraska - Lincoln. It has been accepted for inclusion in Roman L. Hruska U.S. Meat Animal Research Center by an authorized administrator of DigitalCommons@University of Nebraska - Lincoln. 


\title{
Effects of decreased dietary roughage concentration on energy metabolism and nutrient balance in finishing beef cattle ${ }^{1}$
}

\author{
K. E. Hales, *2 T. M. Brown-Brandl,* and H. C. Freetly* \\ * USDA-ARS, U.S. Meat Animal Research Center, Clay Center, NE 68933
}

\begin{abstract}
The optimal roughage concentration required in feedlot diets changes continuously for many reasons such as source, availability, price, and interaction with other ingredients in the diet. Wet distillers grains and solubles (WDGS) are common in finishing diets and they contain relatively high amounts of fiber compared with other grains they replace. Therefore, concentration of roughage could be altered when WDGS are included in feedlot diets. There has been very little data published regarding the effects of roughage concentration on energy metabolism and nutrient balance in beef steers. Therefore, the effects of roughage concentration in dryrolled corn (DRC)-based diets containing 25\% WDGS were evaluated in 8 steers $(\mathrm{BW}=362 \pm 3.71 \mathrm{~kg})$ using a replicated Latin square. Data were analyzed with the fixed effects of dietary treatment and period and random effects of square and steer within square were included in the model. Diets consisted of 25\% WDGS and the balance being DRC and coarsely ground alfalfa hay $(\mathrm{AH})$ replacing corn at $2 \%(\mathrm{AH}-2), 6 \%(\mathrm{AH}-6), 10 \%$ (AH-10), and 14\% (AH-14) of dietary dry matter. As a
\end{abstract}

proportion of GE intake, fecal energy loss increased linearly $(P=0.02)$, and DE decreased linearly $(P=0.02)$ as dietary level of AH increased. Methane energy loss, as a proportion of GE intake, increased linearly $(P<0.01)$ and ME decreased linearly $(P<0.01)$ as dietary concentration of AH increased. Heat production tended $(P=$ $0.10)$ to decrease reaching a minimum of $10 \% \mathrm{AH}$ and increased from 10 to $14 \% \mathrm{AH}$ inclusion. Moreover, as a proportion of GE intake, retained energy (RE) decreased $(P<0.01)$ as AH level increased in the diet. Reasons for the decrease in RE are 1) the increase in fecal energy loss that is associated with decreased ruminal digestibility of NDF when AH replaced DRC and the shift in ruminal VFA produced, 2) the decreased energy available for animal retention when NDF increased linearly as $\mathrm{AH}$ increased in the diet, and 3 ) the methane and heat energy associated with digestion of the fibrous portion of the AH. Neutral detergent fiber and OM excretion also increased linearly $(P<0.01)$ with increasing $\mathrm{AH}$ in the diet. The increased NDF and OM excretion were likely caused by the difference in digestibility of AH and DRC.

Key words: cattle, energy metabolism, finishing diet, roughage

(C) 2014 American Society of Animal Science. All rights reserved.

This article is a U.S. government work, and is not subject to copyright in the United States.
J. Anim. Sci. 2014.92:264-271 doi:10.2527/jas2013-6994

\section{INTRODUCTION}

An optimal level of roughage in feedlot diets is related to many factors such as source, availability, price, and interactions with other ingredients in the diet. A primary focus of the research conducted to evaluate

\footnotetext{
${ }^{1}$ Mention of trade names or commercial products in this article is solely for the purpose of providing specific information and does not imply recommendation or endorsement by the USDA. USDA is an equal opportunity provider and employer. The efforts of K. Sorensen, A. Menke, C. Haussler, C. Felber, and D. Janssen in assisting with the conduct of this research and $\mathrm{C}$. Engle in assisting in the cattle management are greatly appreciated.

${ }^{2}$ Corresponding author: Kristin.Hales@ars.usda.gov

Received August 5, 2013.

Accepted November 13, 2013.
}

roughage concentration in finishing diets has been directed at the mitigation of ruminal acidosis. With the increased inclusion of ethanol coproducts in current feedlot diets, the added roughage concentration required to support optimum cattle performance has decreased because coproducts such as wet distillers grains with solubles (WDGS) have a relatively high concentration of cellulose and hemicellulose compared to the concentrate grain they replace in feedlot diets (Hales et al., 2012). Furthermore, coproducts low in starch may promote a more stable $\mathrm{pH}$ in the ruminal environment allowing for a decreased roughage concentration in finishing diets. Analysis of responses of G:F and ADG when steers were fed dry-rolled corn-based diets with $25 \%$ WDGS and 2, 6, 10, and 14\% were 3 and $7 \%$ for 
G:F and ADG, respectively, as reported by Hales et al. (2013b). Therefore, it is reasonable that the dietary concentration of roughage could be decreased when WDGS are included in feedlot diets.

Currently, there is an absence of data regarding the effects of dietary roughage concentration on energy metabolism and nutrient balance in feedlot cattle. Our hypothesis was that decreasing roughage concentration in finishing diets which included a constant level of WDGS would decrease fecal and methane energy loss and increase retained energy. Our objective was to evaluate the effects of dietary roughage concentration in a dry-rolled corn (DRC)-based diet with WDGS on energy metabolism and nutrient digestibility of finishing beef steers when alfalfa hay (AH) replaced DRC at 2, 6, 10, and $14 \%$ of dietary DM.

\section{MATERIALS AND METHODS}

All animal use protocols were approved by the U.S. Meat Animal Research Center Animal Care and Use Committee.

Steers ( $n=8 ; 362 \pm 3.71 \mathrm{~kg}$ of initial BW) were the MARC II composite breed made up of 1/4 Simmental, 1/4 Angus, 1/4 Hereford, and 1/4 Gelbvieh. During the diet adaptation phase, cattle were housed in 4 partially covered concrete pens ( 2 steers/pen). During the collection phase, cattle were moved to a metabolism facility where they were housed in individual stalls $(87 \mathrm{~cm} \times$ $214 \mathrm{~cm}$ ) equipped with automatic, individual water cups. Before the start of the experiment, cattle were adapted to close human contact in the barn for at least $6 \mathrm{wk}$. During this time, the steers were trained to wear fecal bags and urine harnesses. After adaptation to the collection facility, the steers were stratified by BW and assigned to 1 of 2 Latin square replicates. Each of the 4 periods in the Latin square consisted of an initial 16-d diet adaptation and $5 \mathrm{~d}$ of fecal and urine collections, resulting in a total of $84 \mathrm{~d}$ for the experiment.

Cattle were fed once daily at $0800 \mathrm{~h}$ throughout the experiment and had access to ad libitum feed. Steers had access to fresh water at all times. During the collection periods, orts were weighed daily $24 \mathrm{~h}$ after feeding the day before, and a subsample was saved for later determination of DM content and GE. The dietary treatment consisted of a DRC-based diet with 25\% WDGS and $\mathrm{AH}$ replacing DRC at 2\% (AH-2), 6\% (AH-6), 10\% (AH-10), and 14\% (AH-14) of DM (Table 1). Diets, orts, urine, and feces were weighed daily on a platform scale. Orts, feces, and urine were collected after $24 \mathrm{~h}$ of measurement, for example, if an animal was fed on $\mathrm{d} 1$ at $0800 \mathrm{~h}$, then on $\mathrm{d} 2$ orts would be collected at $0800 \mathrm{~h}$. Additionally, the fecal bag would be changed and urine collected at $0800 \mathrm{~h}$. Diet samples and orts were collected
Table 1. Composition and analyzed nutrient content (DM basis) of dry-rolled corn-based diets with 25\% wet distillers grains with solubles (WDGS) and 2, 6, 10, or $14 \%$ alfalfa hay $(\mathrm{AH})$

\begin{tabular}{lcccc}
\hline \hline & \multicolumn{4}{c}{ Treatment $^{1}$} \\
\cline { 2 - 5 } Item & $\mathrm{AH}-2$ & $\mathrm{AH}-6$ & $\mathrm{AH}-10$ & $\mathrm{AH}-14$ \\
\hline Ingredient, \% & & & & \\
Dry-rolled corn & 68.81 & 64.94 & 61.07 & 57.20 \\
WDGS $^{2}$ & 25.00 & 25.00 & 25.00 & 25.00 \\
Alfalfa hay & 2.00 & 6.00 & 10.00 & 14.00 \\
Urea & 0.95 & 0.82 & 0.69 & 0.56 \\
Supplement $^{3}$ & 3.24 & 3.24 & 3.24 & 3.24 \\
Analyzed composition, \% & & & & \\
DM & 66.69 & 65.61 & 65.19 & 65.34 \\
CP & 18.40 & 18.10 & 18.40 & 19.00 \\
NDF & 14.35 & 15.40 & 18.11 & 20.31 \\
Ether Extract & 5.9 & 5.4 & 5.5 & 5.2 \\
Ash & 5.2 & 4.8 & 4.3 & 4.2 \\
Ca & 0.71 & 0.65 & 0.64 & 0.74 \\
P & 0.49 & 0.49 & 0.44 & 0.50 \\
S & 0.28 & 0.30 & 0.31 & 0.31 \\
\hline
\end{tabular}

${ }^{1}$ Diets were based on dry-rolled corn with $25 \%$ wet distillers grains and solubles with alfalfa hay concentrations of $2 \%$ (AH-2), 6\% (AH-6), 10\% (AH-10), and 14\% (AH-14) of dietary DM.

${ }^{2}$ The average DM content of WDGS during the experiment was $37.26 \%$ and the WDGS was produced solely from corn grain. Additionally, the composite chemical analysis on a DM-basis was as follows: $\mathrm{CP}=28.5 \%$, starch $=$ $8.8 \%, \mathrm{ADF}=13.4 \%, \mathrm{NDF}=26.2 \%$, ether extract $=11.6 \%, \mathrm{TDN}=77.5 \%, \mathrm{Ca}$ $=0.08 \%, P=0.77 \%, \mathrm{Mg}=0.36 \%, \mathrm{~K}=1.02 \%, \mathrm{~S}=0.72 \%$.

${ }^{3}$ Rumensin (Elanco Animal Health, Greenfield, IN) and vitamins and minerals to exceed NRC (1996) requirements were incorporated into a commercial supplement premix.

daily during each collection period. Urine was collected into a polypropylene jug under vacuum where each jug contained $100 \mathrm{~mL}$ of $3.7 \mathrm{~N} \mathrm{HCl}$ to prevent ammonia losses. Feces were collected in a canvas bag attached to a harness. Three percent aliquots of thoroughly mixed urine and feces were collected daily, pooled within steer, and stored at $-17^{\circ} \mathrm{C}$ for later laboratory analyses.

Composited diet, ort, and fecal samples were dried for $48 \mathrm{~h}$ in a forced-air oven at $55^{\circ} \mathrm{C}$. Samples were then ground through a Wiley Mill (Arthur Thomas Co., Philadelphia, PA) to pass through a 1-mm screen. Gross energy was measured via bomb calorimetry for dried diets, orts, feces, and urine. Neutral detergent fiber content was measured on dried diet and fecal samples by placing the diet sample in an individual Ankom fiber bag (F57 Filter Bags; Ankom Technology, Macedon, NY) that was heat sealed. The NDF analysis was performed with an Ankom 200 Fiber Analyzer (Ankom Technology) following the procedures of Van Soest et al. (1991). Heat-stable $\alpha$-amylase and sodium sulfite ( $1 \mathrm{~g} / 100 \mathrm{~mL}$ of NDF solution) were added to the solution during the analysis. The bags containing the residual were then dried for $24 \mathrm{~h}$ at $100^{\circ} \mathrm{C}$ in a forced-air 
oven for quantification of the NDF residue. Ether extract was quantified by refluxing ether over samples in Soxhlet tubes for $18 \mathrm{~h}$. Diet and fecal $\mathrm{N}$ was quantified at a commercial laboratory (Servi-Tech Labs, Hastings, $\mathrm{NE}$ ) using the Kjeldahl method. Wet distillers grains with solubles were delivered from a single supplier to the research area once weekly and stored outside on a concrete pad. Upon arrival, WDGS were sampled for DM content and twice weekly thereafter or anytime a significant weather event occurred such as rain or snow.

Treatment diets were mixed in $60-\mathrm{kg}$ batches 3 times per wk in a small mixer and stored in $400 \mathrm{~L}$ feed wagons. Before mixing, each ingredient was weighed on a platform scale. Ingredients were added to the mixer and each diet was allowed to mix for approximately $10 \mathrm{~min}$. Cleanout of the mixer unit was performed to ensure that no cross-contamination of diets occurred.

Following each collection period, $\mathrm{O}_{2}, \mathrm{CO}_{2}$, and $\mathrm{CH}_{4}$ gases were measured by indirect calorimetry using 8 portable respiration head boxes for $6 \mathrm{~h}$. At least 3 air turnovers were allowed before the gas measurements were determined. The portable box was $0.76 \times 0.76 \times 1.78 \mathrm{~m}$ and had an aluminum frame which was covered with 5-mm clear acrylic sheets. The box was equipped with a $0.76 \times 117-\mathrm{cm}$ opening with a vinyl hood used for attaching around the animal's neck to provide a seal between the box and animal. The animal's daily diet allotment was placed in each box, and generally the cattle consumed $>$ $75 \%$ of the feed offered. Gas exchange was determined by pulling air through the box across a temperature-compensated dry test meter to determine airflow leaving the box. Real-time air temperature and humidity were determined with a Pace Data Logger (XR440; Pace Scientific, Mooresville, NC). Proportional samples of background air entering the box and air exhausted from the box were collected in polyethylene-aluminum-Mylar laminate gas bags to form a composite air sample for the collection period for each individual box. Gas samples were analyzed for $\mathrm{O}_{2}, \mathrm{CO}_{2}$, and $\mathrm{CH}_{4}$ according to Nienaber and Maddy (1985). Measurements from the 6-h period were adjusted to daily measurements by multiplying by 4 . Heat production was calculated using the Brouwer (1965) equation. Before gas measurements were collected, each head box was calibrated for $\mathrm{O}_{2}$ consumed and $\mathrm{CO}_{2}$ produced by burning absolute ethanol with alcohol lamps. Recoveries were greater than $98 \%$ in all head boxes.

All data were analyzed as a Latin square design using the Mixed procedure of SAS (SAS Inst. Inc., Cary, NC). The model included fixed effects of period and dietary treatment and the random effects of square and steer within square. Contrast statements were used to test the linear and quadratic effects of $\mathrm{AH}$ concentration in the diet. Effects were considered significant at
$P$-value of $\leq 0.05$, with tendencies declared at $P$-values between 0.05 and 0.10 .

\section{RESULTS}

The experimental diets are presented in Table 1. The diets ranged from 18.1 to $19.0 \%$ in $\mathrm{CP}$ and were formulated for a minimum of $8.0 \%$ degradable intake protein (DIP) and ether extract (EE) concentration ranged from 5.2 to $5.9 \%$ among diets. The NDF concentration increased in the diet as the AH concentration also increased.

Dry matter intake (Table 2) was not different among treatments, but the range in difference was $8.7 \%$. Gross energy intake ranged from 33.18 to $35.99 \mathrm{Mcal} / \mathrm{d}$ among treatments. Fecal energy loss as a percentage of GE intake increased linearly $(P<0.02)$ as dietary AH concentration increased while $\mathrm{DE}(\mathrm{Mcal} / \mathrm{d} ; P=0.08)$ tended to decrease, and $\mathrm{DE}$ as a proportion of GE intake also decreased $(P=$ 0.02 ). Urinary energy losses (Mcal or as a $\%$ of GE intake) were not different $(P>0.24)$ with increased concentration of AH in the diet. Methane energy loss in Mcal $(P=0.01)$ and as a proportion of GE intake $(P<0.01)$ increased as the concentration of AH increased from 2 to $14 \%$ in the diet. Dietary metabolizable energy concentration (Mcal) tended $(P=0.06)$ to decrease as AH increased in the diet. Similarly, as a proportion of GE intake, ME decreased linearly $(P<0.01)$ as AH concentration was increased. The ratio of ME to DE decreased linearly $(P$ $<0.01)$ as AH concentration increased in the diet. Heat production (Mcal) was not different $(P>0.31)$ across the diets; however, as a proportion of GE intake, HP tended $(P=0.10)$ to respond quadratically decreasing to $10 \% \mathrm{AH}$ then subsequently increasing. Retained energy (RE; Mcal and as a proportion of GE intake) decreased linearly $(P<$ 0.02 ) as $\mathrm{AH}$ was increased from 2 to $14 \%$ in the diet.

Nitrogen balance is presented in Table 3. Nitrogen intake was not different $(P>0.28)$ and ranged from 217.71 to $234.63 \mathrm{~g} / \mathrm{d}$ across diets. Daily grams of $\mathrm{N}$ excretion in the urine $(P>0.73)$ and feces $(P>0.15)$ were not different as $\mathrm{AH}$ increased in the diet from 2 to $14 \%$ of DM. No differences were noted in total $\mathrm{N}$ excretion as the concentration of $\mathrm{AH}$ increased from 2 to $14 \%$ of the diet. Likewise, as a proportion of total $\mathrm{N}$ excretion, urinary $(P>0.30)$ and fecal $(P>0.30) \mathrm{N}$ excretion did not different among diets. Urinary $\mathrm{N}$ excretion, as a proportion of $\mathrm{N}$ intake, was not different $(P>0.48)$ among diets; however, fecal $\mathrm{N}$ excretion $(P=$ 0.03 ) linearly increased as AH increased from 2 to $14 \%$ of the diet. As a proportion of $\mathrm{N}$ intake, apparent $\mathrm{N}$ digestibility decreased linearly $(P=0.03)$ with increased concentration of $\mathrm{AH}$ and also decreasing concentration of dietary urea. Additionally, $\mathrm{N}$ retained (g/d $P=0.09$; as a $\%$ of N intake $P=0.13$ ) tended to decrease linearly as AH increased in the diet. No differences $(P>0.19)$ 
Table 2. Influence of feeding dry-rolled corn-based diets with $25 \%$ wet distillers grains with solubles (WDGS) and $2,6,10$, and $14 \%$ alfalfa hay on energy partitioning in finishing steers fed at ad libitum intake ${ }^{1}$

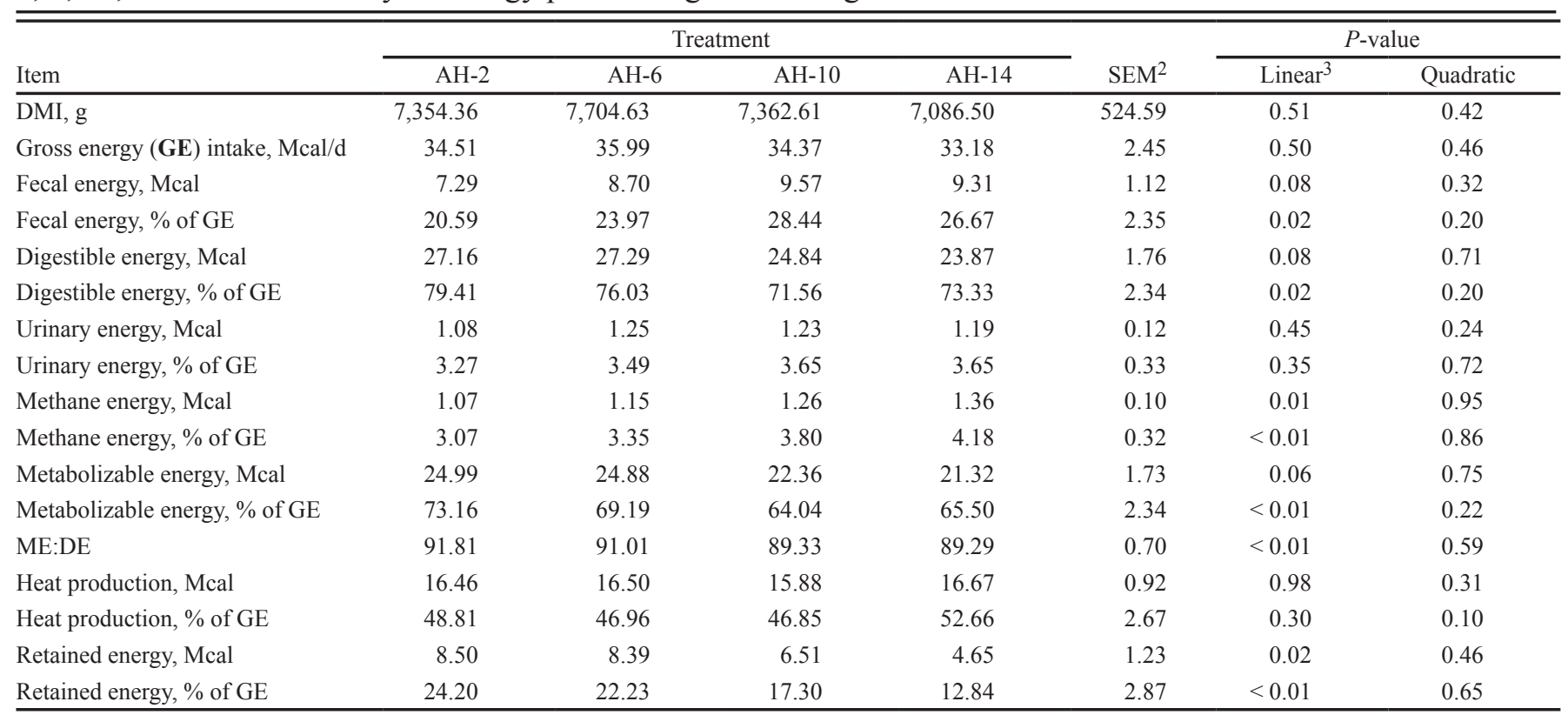

${ }^{1}$ Diets were based on dry-rolled corn with $25 \%$ wet distillers grains and solubles with alfalfa hay (AH) concentrations of $2 \%(\mathrm{AH}-2), 6 \%$ (AH-6), $10 \%$ (AH$10)$, and $14 \%$ (AH-14) of dietary DM.

${ }^{2}$ Pooled standard error of the least squares means $(n=8)$.

${ }^{3}$ Observed significance levels for treatment comparisons.

in $\mathrm{N}$ retained, as a proportion of digested $\mathrm{N}$, were observed across treatments.

Dry matter digestibility (DMD), NDF, and EE balance are presented in Table 4. Dry matter digestibility decreased linearly $(P=0.02)$ as $\mathrm{AH}$ increased in the diet. Intake of NDF increased linearly $(P<0.01)$ when dietary $\mathrm{AH}$ concentration increased from 2 to $14 \%$ of DM. Furthermore, fecal excretion of NDF also increased linearly $(P<0.01)$ with increased AH in the diet. A tendency $(P=0.10)$ for increased $g$ of NDF digested as AH was increased in the diet was observed. Digestibility of NDF as a proportion of NDF intake to responded quadratically $(P=0.10)$, decreasing at a rate reaching a minimum at $10 \% \mathrm{AH}$ inclusion and increasing from 10 to $14 \% \mathrm{AH}$ inclusion in the diet.

Organic matter intake did not differ among diet treatments $(P>0.40)$; however, fecal OM excretion had a tendency $(P=0.06)$ to increase linearly as the concentration of $\mathrm{AH}$ in the diet increased. As a proportion of intake, OM digestibility $(P=0.05)$ responded in a quadratic manner decreasing from 2 to $10 \% \mathrm{AH}$ inclusion where digestibility reached a minimum and then increased from 10 to $14 \% \mathrm{AH}$ in the diet.

\section{DISCUSSION}

It was expected, that dietary NDF concentration would increase as AH concentration increased. The tendency for increased fecal energy loss as a percentage of
GE intake is plausible since AH has a TDN value of 58\% replaced DRC with a TDN value of $90 \%$ (NRC, 1996). It is our belief that fecal energy was derived primarily from NDF. As a consequence of increased fecal energy loss, there was a corresponding decrease in $\mathrm{DE}$ as the concentration of $\mathrm{AH}$ increased in the diet, which is consistent with the relative difference between the TDN value of AH and DRC. Others (Cole et al., 1976a,b) have reported that higher roughage levels in concentrate-based diets reduce starch digestibility in the intestine and throughout the total tract; therefore, it is plausible that some of the fecal energy was comprised of starch as well. A lack of treatment differences in urinary energy loss (Mcal or as a $\%$ of GE intake) were expected. Differences in urinary energy loss often result from differences in urinary $\mathrm{N}$ concentration, and in our study, the differences in dietary $\mathrm{N}$ concentration were minor (ranging from 2.9 to $3.0 \%$ ). The increase in energy loss attributable to $\mathrm{CH}_{4}$ with increased dietary level of AH is likely a result of differences in digestibility (greater for DRC than $\mathrm{AH}$ ) and ruminal residence time being longer for $\mathrm{AH}$ than DRC. Beauchemin and McGinn (2005) reported $\mathrm{CH}_{4}$ losses as a proportion of GE of $2.8 \%$ when cattle were fed DRC-based diets while Hales et al. (2012) reported losses of 2.47 and $3.04 \%$ of GE for steam-flaked corn and DRC-based diets, respectively. When evaluated as a proportion of $\mathrm{GE}$ intake, our $\mathrm{CH}_{4}$ losses are comparable to that previously reported by Hales et al. (2012) for steers fed DRC-based diets with 30\% WDGS even 
Table 3. Influence of feeding dry-rolled corn-based diets with $25 \%$ wet distillers grains with solubles (WDGS) and $2,6,10$, and $14 \%$ alfalfa hay on $\mathrm{N}$ balance in finishing steers fed at ad libitum intake ${ }^{1}$

\begin{tabular}{|c|c|c|c|c|c|c|c|}
\hline \multirow[b]{2}{*}{ Item } & \multicolumn{4}{|c|}{ Treatment } & \multirow[b]{2}{*}{ SEM $^{2}$} & \multicolumn{2}{|c|}{$P$-value } \\
\hline & $\mathrm{AH}-2$ & AH-6 & AH-10 & AH-14 & & Linear $^{3}$ & Quadratic \\
\hline $\bar{N}$ intake, g/d & 234.63 & 225.82 & 217.73 & 217.71 & 15.586 & 0.28 & 0.69 \\
\hline \multicolumn{8}{|l|}{$\mathrm{N}$ excretion, $\mathrm{g} / \mathrm{d}$} \\
\hline Urine & 126.36 & 135.40 & 123.42 & 125.86 & 10.97 & 0.76 & 0.73 \\
\hline Feces & 47.04 & 51.94 & 58.08 & 55.57 & 6.632 & 0.15 & 0.44 \\
\hline Total & 173.40 & 187.34 & 181.50 & 181.43 & 15.526 & 0.72 & 0.55 \\
\hline Feces & 27.00 & 28.20 & 32.15 & 29.20 & 2.679 & 0.30 & 0.41 \\
\hline \multicolumn{8}{|c|}{$\mathrm{N}$ excretion, $\%$ of $\mathrm{N}$ intake } \\
\hline Urine & 54.42 & 60.13 & 58.14 & 58.28 & 4.000 & 0.58 & 0.48 \\
\hline Feces & 19.77 & 23.10 & 27.29 & 24.22 & 2.073 & 0.03 & 0.07 \\
\hline \multicolumn{8}{|l|}{ Apparent $\mathrm{N}$ digested } \\
\hline $\mathrm{g} / \mathrm{d}$ & 61.23 & 38.48 & 36.22 & 36.29 & 9.784 & 0.09 & 0.26 \\
\hline$\%$ of $\mathrm{N}$ intake & 25.81 & 16.78 & 14.57 & 17.50 & 3.799 & 0.13 & 0.13 \\
\hline$\%$ of digested $\mathrm{N}$ & 32.03 & 21.96 & 19.78 & 22.86 & 4.899 & 0.19 & 0.20 \\
\hline
\end{tabular}

${ }^{1}$ Diets were based on dry-rolled corn with $25 \%$ wet distillers grains and solubles with alfalfa hay $(\mathrm{AH})$ concentrations of $2 \%(\mathrm{AH}-2), 6 \%(\mathrm{AH}-6), 10 \%(\mathrm{AH}-$ $10)$, and $14 \%(\mathrm{AH}-14)$ of dietary DM.

${ }^{2}$ Pooled standard error of the least squares means $(n=8)$.

${ }^{3}$ Observed significance levels for treatment comparisons.

though the breed composition and BW of the steers used in each study differed. The decrease in ME observed as a proportion of GE intake is thought to be primarily driven by the fecal energy and $\mathrm{CH}_{4}$ loss.

The ME to DE ratio observed in the current experiment was surprising. According to the NRC (2000), the ratio of ME to $\mathrm{DE}$ is about $80 \%$, but can vary considerably as a result of intake, age of animal and feed source. In the current experiment, the ratio of ME to DE ranged from 89 to $92 \%$. This disparity could be caused by many factors including the method of data collection, which was respiration calorimetry in the current experiment and serial slaughter in past experiments. Quantification of ME in serial slaughter experiments would be achieved by using an equation to estimate $\mathrm{CH}_{4}$ production, and in the current experiment $\mathrm{CH}_{4}$ was measured. Improvements in cattle genetics may also account for differences in the ratio of ME to DE.

Dietary factors such as level of dietary fat may also help explain why the ratio of ME to DE is greater in the current experiment than reported by the NRC (2000). In finishing cattle, there is a curvilinear relationship between gross and retained energy where consistent levels of energy intake result in progressively less amounts of energy retention. This is a result of the metabolizable energy of the diet decreasing when level of intake increases (Geay, 1984). This is likely caused by an increased rate of passage, a decreased digestibil- ity of dietary components, increased fecal energy loss and little change in $\mathrm{CH}_{4}$ production and urinary energy losses. In the current experiment, WDGS was included in all diets at $25 \%$ of DM, and EE ranged from approximately 5 to $6 \%$. The inclusion of fat in the current diets (primarily from WDGS) increased the ME concentration of the diets and in turn, likely increases the efficiency of ME utilization.

The decrease in RE (Mcal and as a \% of GE intake) with increased level of AH was primarily caused by the coinciding increases in energy loss through the feces and $\mathrm{CH}_{4}$. The energetic loss in feces and $\mathrm{CH}_{4}$ decrease the total energy available for retention within the animal. This decrease in energy available for retention contributed to the decrease in $\mathrm{RE}$ as $\mathrm{AH}$ increased in the diet. The cattle fed greater amounts of AH may have simply retained less energy because there was less available for retention because of the fecal and $\mathrm{CH}_{4}$ loss.

The decrease in RE observed with increased $\mathrm{AH}$ could have been the result of a decrease in total VFA concentration due to changes in site of digestion. Plausibly, diets higher in $\mathrm{AH}$ may have a greater level of fermentation of the diet occurring in the lower gut; whereas, diets with less AH would promote increased ruminal fermentation because of the greater dietary starch content (data not reported). Although the lower gut is capable of digesting starch, the efficiency of this process ranges from 45 to $85 \%$ of starch entering the 
Table 4. Influence of feeding dry-rolled corn-based diets with $25 \%$ wet distillers grains with solubles (WDGS) and $2,6,10$, and $14 \%$ alfalfa hay $(\mathrm{AH})$ on dry matter digestibility, NDF, and $\mathrm{OM}$ balance in finishing steers fed at ad libitum intake ${ }^{1}$

\begin{tabular}{|c|c|c|c|c|c|c|c|}
\hline \multirow[b]{2}{*}{ Item } & \multicolumn{4}{|c|}{ Treatment } & \multirow[b]{2}{*}{ SEM $^{2}$} & \multicolumn{2}{|c|}{$P$-value } \\
\hline & AH-2 & AH-6 & $\mathrm{AH}-10$ & $\mathrm{AH}-14$ & & Linear $^{3}$ & Quadratic \\
\hline Dry matter digestibility & 80.31 & 77.32 & 72.99 & 74.34 & 2.24 & 0.02 & 0.26 \\
\hline \multicolumn{8}{|l|}{ NDF } \\
\hline Intake, $\mathrm{g} / \mathrm{d}$ & $1,041.32$ & $1,194.44$ & $1,316.45$ & $1,450.90$ & 95.14 & $<0.01$ & 0.89 \\
\hline Fecal excretion, g/d & 428.95 & 562.84 & 645.06 & 680.60 & 66.86 & $<0.01$ & 0.37 \\
\hline Digested, g/d & 610.92 & 631.60 & 672.52 & 770.31 & 79.70 & 0.10 & 0.57 \\
\hline Intake, $\mathrm{g} / \mathrm{d}$ & $7,032.36$ & $7,366.17$ & $7,010.92$ & $6,723.13$ & 500.93 & 0.45 & 0.40 \\
\hline Fecal excretion, g/d & $1,359.80$ & $1,628.74$ & $1,790.53$ & $1,770.22$ & 214.33 & 0.06 & 0.36 \\
\hline Digested, g/d & $5,664.06$ & $5,737.43$ & $5,227.01$ & $4,952.91$ & 368.84 & 0.07 & 0.57 \\
\hline Digestibility, $\%$ of intake & 81.17 & 78.07 & 73.88 & 75.00 & 2.22 & 0.15 & 0.05 \\
\hline
\end{tabular}

${ }^{1}$ Diets were based on dry-rolled corn with $25 \%$ wet distillers grains and solubles with alfalfa hay (AH) concentrations of 2\% (AH-2), 6\% (AH-6), 10\% (AH$10)$, and $14 \%(\mathrm{AH}-14)$ of dietary DM.

${ }^{2}$ Pooled standard error of the least squares means $(n=8)$.

${ }^{3}$ Observed significance levels for treatment comparisons.

duodenum with the limiting factor being the quantity of pancreatic amylase secreted (Huntington, 1997). In the current experiment, the $14 \%$ level of $\mathrm{AH}$ had the least amount of dietary starch and the least amount of ME; therefore, if digestion was shifted to the lower gut and efficiency was decreased, this could explain differences in energetic costs and ultimately RE.

Sarwar et al. (1992) reported a linear increase in total VFA concentration as NDF from forage decreased in the diet of ruminally cannulated Holstein cows. Additionally, Sarwar et al. (1992) observed a linear decrease in acetate and a linear increase in propionate when diets had less NDF derived from forage. A subsequent decrease in the acetate to propionate ratio was also noted and it was hypothesized that the results were a result of more extensive ruminal fermentation or a decreased rumen volume or dilution rate associated with low-fiber diets (Sarwar et al., 1992). Molar proportions of propionate are often inversely related to the rumen fluid dilution rate (Estell and Galyean, 1985), whereas concentration of acetate in the rumen are usually elevated. Slower fluid dilution rate has been observed with increased concentrate in the diet (Cole et al., 1976b; Goetsch and Galyean, 1982) while an increased proportion of roughage in the diet should increase the fluid dilution rate (Owens and Isaacson, 1977). An increase in fluid dilution rate is typically associated with an increase in ruminal ammonia concentrations (Estell and Galyean, 1985) which must be maintained above a critical concentration to ensure adequate microbial growth, digestion, and animal feed intake.

Reynolds et al. (1991) evaluated the effects of dietary forage-to-concentrate ratio on balance of energy and nitrogen in the portal-drained viscera and $\mathrm{O}_{2}$ consumption in beef heifers fed isoenergetic diets with either $75 \% \mathrm{AH}$ or $75 \%$ concentrate. They hypothesized that the differences in the mass of ruminal epithelial tissues of heifers fed the different diets changed the rate of protein turnover and ion transport. The portal-drained viscera and $\mathrm{O}_{2}$ consumption were thought to be a result of changes in the quantities of VFA absorbed (Reynolds et al., 1991). They noted that increased proportions of acetate and butyrate produced in the rumen may stimulate epithelial hypertrophy and, therefore, increase energetic cost to the animal (Reynolds et al., 1991). In the current experiment, a majority of the differences observed for RE may be related to VFA absorption with steers fed diets with greater levels of $\mathrm{AH}$ having a greater concentration of ruminal acetate and butyrate relative to propionate concentrations. These shifts in VFA profiles away from propionate could explain the decreased RE observed with increased AH in the diet, which is supported by previous research (Reynolds et al., 1991; Sarwar et al., 1992).

The linear increase in $\mathrm{N}$ excretion as a proportion of $\mathrm{N}$ intake is in contrast with Hales et al. (2013a) that reported fecal $\mathrm{N}$ excretion as a proportion of $\mathrm{N}$ intake decreased linearly as the inclusion of WDGS increased in the diet. Part of the reason for the discrepancy in their data and the current experiment could be that WDGS was increased in the experiment of Hales et al. (2013a), yet it was held constant at $25 \%$ of DM in the current experiment. It is likely that the increase observed by Hales et al. (2013a) WDGS shifted $\mathrm{N}$ excretion from feces to urine. Furthermore, apparent $\mathrm{g} / \mathrm{d}$ of $\mathrm{N}$ digested and apparent $\mathrm{N}$ digested as a proportion of $\mathrm{N}$ intake both decreased linearly as $\mathrm{AH}$ increased in the diet. 
Additionally, in the current study, the linear decreases observed in apparent $\mathrm{g} / \mathrm{d}$ of $\mathrm{N}$ digested and apparent $\mathrm{N}$ digested as a proportion of $\mathrm{N}$ intake are in contrast with the $\mathrm{N}$ balance results of Hales et al. (2013a). In their experiment, cattle were fed increasing concentrations of WDGS in steam-flaked corn-based diets and apparent $\mathrm{N}$ digested ( $\mathrm{g} / \mathrm{d}$ and as a proportion of $\mathrm{N}$ intake) increased linearly with increasing WDGS concentration.

The linear increase in DMD was expected because of the difference in digestibility of AH vs. DRC. The DMD observed for the AH-10 treatment is less than expected and the reason is not understood by the authors. The linear increase reported for NDF intake is by design as $\mathrm{AH}$ was increased in the diet from 2 to $14 \%$ of DM and NDF concentration of the diet increased. Likewise, the increase in fecal NDF excretion is expected given this increase was primarily caused by the increased NDF intake and quadratic response noted for NDF digestibility. Crawford et al. (2008) reported no differences in fecal NDF output as roughage increased in the diet from 3.8 to 7.6 to $11.4 \%$ of DM. Cole et al. (1976a) reported that with increasing dietary roughage concentration, cellulose digestion increased, which is an observation that is not consistent with those of the current study. Furthermore, the increase in NDF intake and excretion likely contributed to the depression in $\mathrm{RE}$ as $\mathrm{AH}$ increased in the diet. It is likely that RE was decreased because the increase in fecal NDF which represents a decrease in energy available for retention in the animal.

In the current experiment, ruminal microorganisms in the AH-14 diet could be comprised of more fibrolytic bacteria such as Fibrobacter succinogenes and Butyrivibrio fibrisolvens vs. Streptococcus bovis and Selenomonas ruminantium, which would utilize starch more efficiently. Additionally, the form and composition of the fiber not derived from AH (WDGS and corn-derived fiber) could have affected the digestibility of NDF. Ruminal $\mathrm{pH}$ is also an important consideration regarding NDF digestibility since fibrolytic bacteria are sensitive to low $\mathrm{pH}$. Fibrobacter succinogenes and Butyvibrio fibrisolvens cannot tolerate a ruminal $\mathrm{pH}$ below 5.7 (Russell and Wilson, 1996). If exposed to this low ruminal $\mathrm{pH}$ bacteria regulate their intracellular $\mathrm{pH}$ where the $\mathrm{pH}$ gradient across the cell membrane is increased and the electrical potential declines. This is followed by an inability to take up carbohydrate and protonmotive force across the cell membrane ceases. Additionally, some bacteria decrease their intracellular $\mathrm{pH}$ as extracellular $\mathrm{pH}$ declines and growth ceases when intracellular $\mathrm{pH}$ falls below 6 . The ruminal $\mathrm{pH}$ of finishing beef cattle fed concentrate-based diets is typically less than 6 (Russell and Wilson, 1996).

The increase in fecal OM excretion is likely a direct result of the increased fecal NDF excretion and decrease in DMD as $\mathrm{AH}$ increased in the diet as discussed previ- ously and coincides with the tendency for a decrease in the quantity of digestible OM. Crawford et al. (2008) reported that fecal $\mathrm{OM}$ output tended to increase as roughage concentration increased in the diet from 3.8 to $11.4 \%$, while Zinn et al. (1994) reported that increasing forage level in the diet from 10 to $20 \%$ of DM decreased total tract digestibility of OM, which is in agreement with the current experiment. In the present study, a primary reason for the quadratic response observed for OM digestibility expressed as a proportion of OM intake is the quadratic response in NDF digestibility.

\section{CONCLUSION}

Methane energy increased linearly as the concentration of $\mathrm{AH}$ increased in the diet due to the difference in substrate digestibility of AH and DRC. Retained energy as a proportion of GE intake decreased as AH level increased in the diet as a result of 1) the increase in fecal energy loss that is associated with decreased ruminal digestibility of NDF when AH replaced DRC and the shift in ruminal VFA produced, 2) the decreased energy available for animal retention when NDF increased linearly as $\mathrm{AH}$ increased in the diet, and 3) the methane and heat energy associated with digestion of the fibrous portion of the AH. Neutral detergent fiber and OM excretion also increased linearly as a result of the linear decrease in DMD with increased AH level in the diet. The results of this research are interpreted to suggest that nutrient retention and excretion of feedlot cattle can be improved by minimizing the amount of roughage used in DRCbased finishing diets which include a moderate level of wet distillers grains with solubles.

\section{LITERATURE CITED}

Beauchemin, K. A., and S. M. McGinn. 2005. Methane emissions from feedlot cattle fed barley or corn diets. J. Anim. Sci. 83:653-661.

Brouwer, E. 1965. Report of sub-committee on constants and factors. In: Energy Metabolism, EAAP Publ. No. 11, Troon, UK. p. 441.

Cole, N. A., R. R. Johnson, and F. N. Owens. 1976a. Influence of roughage level on the site and extent of digestion of whole shelled corn by beef steers. J. Anim. Sci. 43:483-489.

Cole, N. A., R. R. Johnson, F. N. Owens, and J. R. Males. 1976b. Influence of roughage level and corn processing method on microbial protein synthesis by beef steers. J. Anim. Sci. 43:497-503.

Crawford, G. I., C. D. Keller, J. J. Wagner, C. R. Krehbiel, G. E. Erickson, M. B. Crombie, and G. A. Nunnery. 2008. Effects of calcium magnesium carbonate and roughage level on feedlot performance, ruminal metabolism, and site and extent of digestion in steers fed high-grain diets. J. Anim. Sci. 86:2998-3013.

Estell, R. E., II, and M. L. Galyean. 1985. Relationship of rumen fluid dilution rate and rumen fermentation and dietary characteristics of beef steers. J. Anim. Sci. 60:1061-1071.

Geay, Y. 1984. Energy and protein utilization in growing cattle. J. Anim. Sci. 58:766-768. 
Goetsch, A. L., and M. L. Galyean. 1982. Effect of dietary concentrate level on rumen fluid dilution rate. Can. J. Anim. Sci. 62:649-654.

Hales, K. E., N. A. Cole, and J. C. MacDonald. 2012. Effects of corn processing method and dietary inclusion of wet distillers grains with solubles on energy metabolism, carbon-nitrogen balance, and methane emissions of cattle. J. Anim. Sci. 90:3174-3185.

Hales, K. E., N. A. Cole, and J. C. MacDonald. 2013a. Effects of increasing concentrations of wet distillers grains with solubles on energy metabolism, carbon-nitrogen balance, and methane emissions of cattle. J. Anim. Sci. 91:819-828.

Hales, K. E., H. C. Freetly, S. D. Shackelford, and D. A. King. 2013b. Effects of roughage concentration in dry-rolled corn-based diets containing wet distillers grains with solubles on performance and carcass characteristics of finishing beef steers. J. Anim. Sci. 91:3315-3321.

Huntington, G. B. 1997. Starch utilization by ruminants: From the basics to the bunk. J. Anim. Sci. 75:852-867.

Nienaber, J. A., and A. L. Maddy. 1985. Temperature-controlled multiple chamber indirect calorimeter-design and operation. Trans. ASAE 28:555-560.
NRC. 2000. Nutrient requirements of beef cattle. 7th ed. Natl. Acad. Press, Washington, DC.

NRC. 1996. Nutrient requirements of beef cattle. 7th ed. Natl. Acad. Press, Washington, DC.

Owens, F. N., and H. R. Isaacson. 1977. Rumen microbial yields: Factors influencing synthesis and bypass. Fed. Proc. 36:198-202.

Reynolds, C. K., H. F. Tyrrell, and P. J. Reynolds. 1991. Effects of diet forage-to-concentrate ratio and intake on energy metabolism in growing beef heifers: Whole body energy and nitrogen balance and visceral heat production. J. Nutr. 91:994-1003.

Russell, J. B., and D. B. Wilson. 1996. Why are ruminal cellulolytic bacteria unable to digest cellulose at low pH? J. Dairy Sci. 79:1503-1509.

Sarwar, M., J. L. Firkins, and M. L. Eastridge. 1992. Effects of varying forage and concentrate carbohydrates on nutrient digestibilities and milk production by dairy cows. J. Dairy Sci. 75:1533-1542.

Van Soest, P. J., J. B. Robertson, and B. A. Lewis. 1991. Methods for dietary fiber, neutral detergent fiber, and nonstarch polysaccharides in relation to animal nutrition. J. Dairy Sci. 74:3583-3597.

Zinn, R. A., A. Plascencia, and R. Barajas. 1994. Interaction of forage level and monensin in diets for feedlot cattle on growth performance and digestive function. J. Anim. Sci. 72:2209-2215. 